an iron-pyrrol compound, plays an important part here: activated by indophenoloxidase, it acts as an intermediate carrier of hydrogen to oxygen from the various substrates activated by the dehydrogenases.

Warburg considers that his respiratory enzyme, again an iron-pyrrol derivative, controls the whole field of oxidations. It shows no spectrum, in contrast to cytochrome, but forms reversible combinations with carbon monoxide as well as oxygen, the former of which is decomposed by light. By examining the effectiveness of different wave-lengths in restoring respiration after it had been inhibited by carbon monoxide, Warburg was able to determine the absorption spectrum of the enzyme, since light must be absorbed by the carbon monoxide compound in pro. portion to its effectiveness in dissociating it.

Another path for the transport of hydrogen to oxygen is that associated with the reduction and oxidation of glutathione. Quantitatively it is less prominent than the cytochrome path, but it is essential to the normality of the cell. The cytoplasm of the latter appears to be a lyophil colloidal system in which the micellæ or particles which form the internal phase must be diverse in respect of their surfaces, and probably no small proportion of these surfaces have catalytic properties. Considering the size of the cell and that as much as 75 per cent of cytoplasm is water, of which much is free, it may be assumed that diffusion, as known in macro systems, plays only a negligible part in the velocity of change here, and that contacts between substrate molecules and dispersed particles with catalytic surfaces must continually occur. In such a system a multiplicity of reactions does not appear impossible, whilst the immense numbers of cells in a tissue permit of macroscopic quantities being metabolised.

\title{
Sir Ambrose Fleming and the Physical Society of London
}

THE meeting of the Physical Society held on Feb. 19 marked an event which is probably unique in the history of learned societies. If we open the Society's first minute book (which has fortunately been preserved) we find that the young Society held its first business meeting on Feb. 14, 1874, when, 29 members being present, a list of officers was drawn up. Dr. J. H. Gladstone, F.R.S., father-in-law of the present Prime Minister, was elected to the presidential chair; Profs. Grylls Adams and Carey Foster were appointed as vice-presidents ; Dr. E. Atkinson and Prof. A. W. Reinold were joint secretaries, and-the holder of an office which has fallen into abeyance-Prof. Frederick Guthrie was appointed as the Society's demonstrator.

The next record on the minutes must be transcribed literatim. It reads :- "A mèeting of the Society was held in the Physical Laboratory, South Kensington Museum, at 3 P.M. on Saturday, March 21st [1874], Dr. Gladstone in the chair. There were about 35 members present. The chairman gave a brief description of the objects and organisation of the Society, and noticed the very favourable circumstances under which the Society originated as compared with those attending the origin of its parent, the Royal Society. He announced that 99 gentlemen had already expressed their desire to join the Society as original members."

"J. A. Fleming, B.Sc., read a paper on the new Contact Theory of the Galvanic Cell. . . . Professor F. Guthrie exhibited experiments illustrating the distribution of a galvanic current on entering and leaving a conducting medium." . . .

"Prof. G. C. Foster, Dr. Wright, and Dr. Gladstone took part in the discussion of the communications."

Can any other society produce such a record ? It may be that a greater span of years separated Liveing's first and last papers read before the Cambridge Literary and Philosophical Society, but we know of no other instance in which the reader of the first paper at the first scientific meeting of a society has survived to communicate a paper to the society nearly sixty years later.

Inspection of the list of members published in 1930 shows that, of the founder fellows, four-Armstrong, Fleming, Schuster, and Unwin-are still with us. Lodge joined the Society in February 1875, and of those who entered the ranks in the 'seventies, fourteen still remained at the time of publication of the list consulted. President and Council have long since
disappeared-Carey Foster was probably the last survivor of the original officers-but it would be in. teresting to know if any of the early members were present when "J. A. Fleming, B.Sc." presented his paper.

It is a far cry from the contact theories of 1875 to the wave mechanics of 1932, and Sir Ambrose Fleming has not only made history in this interval, but also still holds a place on the stage of contemporary events. $\mathrm{He}$ has read some thirty-five papers before the Society, and his latest paper, on "Electrons and Light Quanta", admirably illustrates the conservation of his powers as teacher and experimenter.

In his introductory section, Sir Ambrose states, clearly and succinctly, the fundamental facts concerning the antinomies, which, even though as yet un. solved, have almost ceased to perplex us. He calculates the value of the mean energy density of bright sunlight at earth distance, and, using four methods, he obtains: from the mean of 10 equidistant ordinates of the Planck curve, 48 ; from the solar constant, 45 ; from the Stefan constant, 54 ; from the integration of the Planck equation, 55: all expressed in micro-ergs per cubic centimetre. As the illumination of bright sunlight is about 13,000 candle-feet at normal incidence on a white surface, it is possible to estimate the radiation density of other light beams and the average number of photons per cubic centimetre.

Experimentally, Sir Ambrose proceeded to investigate the question, which he states thus: "If then a beam of light can in any way be regarded as a stream of photons or light quanta each having energy and mass, and if the wave energy is electromagnetic in nature, the question arises whether a stream of electrons moving along a beam of light would have their velocity increased or diminished according as they moved with or against the direction of propagation of the light".

As a preliminary experiment with an arc lamp showed no result, Sir Ambrose employed a powerful beam of X-rays. The source of electrons was a special form of Fleming thermionic valve with a dullemitter filament and two grid anodes of rectangular section fixed on either side. Hence if "a beam of radiation was passed transversely across the valve the electrons on one side of the filament moved against the radiation and on the other side with it ". A simple circuit was arranged which would show by means of a differential galvanometer whether the

No. 3252, VoL. 129] 
incidence of the $\mathrm{X}$-ray beam produced any steady variation from equality in the two electron streams to the two anodes of the valve. No change was detected, although the galvanometer was competent to show a change of 0.05 per cent of the anode electroncurrents to the grids. Alitan Ferguson.

\section{Archæology of Eastern Colorado}

THE archæological survey of eastern Colorado carried out in the summer of 1930 by the University of Denver and the Colorado Museum of Natural History, under the direction of Dr. E. B. Renaud, with the assistance of a subsidy from the Smithsonian Institution, is the first systematic archæological work undertaken in that area, and links up the exploration of south-west Colorado on one side, and of Nebraska and States east on the other. Ten thousand miles were covered in ten weeks. A large number of surface finds were collected, but no excavation was possible in the time. The report of Dr. Renaud and his assistants (published by the University of Denver, Anthropological Department) states that few important sites were left unvisited, and the collections and notes, while not exhaustive, are fairly representative of the Indian culture of Colorado.

The area of closest settlement is in the north-west, in Larimer County, with thirty-eight sites. The contiguous counties, extending from the Rocky Mountains to the States of Nebraska and Kansas without a break, form a vast central group separated by a trough from the smaller and isolated north-west group.

The camp site is the most common (247). Here flaked artefacts and chips are fairly well grouped. Old fireplaces and tipi-rings-stone circles, on which the skins rested, marking the base of the tent-are the most certain criterion of a camp site. An unexpected number of the grinding-stones known as mano, or hand-stone, were found. The mano is smaller in the pueblo area. Pottery, previously accounted unknown or rare in the western plains, was recorded on fifty-five sites. Fifty-two workshop sites and fifteen rock-shelters were visited. Petroglyphs, rarely painted and most commonly pecked, were found on fourteen sites. Dr. Renaud has made a careful study of the stone implements, comparing them exhaustively with those of the stone age of Europe and other parts of America. The greater number are non-palæolithic, next in importance being Mousterian-like points, scrapers, and flakes.

In 1931, according to a communication we have received from the Department of Anthropology in the University of Denver, the expedition covered the archæologically rich area known as the "Spanish Diggings" in the neighbourhood of Cheyenne and Larimer. About two hundred Indian sites were visited and recorded, and a large number of artefacts were collected. The pictographs were fewer in number than was expected. Pottery was found on a number of sites, and a number of camps showed tipi-rings. The expedition was particularly impressed by the resemblance of old quarries, from which red chert, yellow jasper, and quartzite have been obtained, to the prehistoric quarries of western Europe, except for the fact that the latter had yielded flint. The relative age of these quarries is being investigated by the examination of the growth of lichen. A rapid excursion was made to north-east Wyoming, archæologically a much less interesting area; but it is anticipated that western Wyoming, when its turn comes for exploration, will yield interesting remains, especially in the form of pictographs.

$$
\text { No. 3252, VoL. 129] }
$$

\section{University and Educational Intelligence}

BIRMINGHam. - In his report to the annual meeting of the Court of Governors held on Feb. 25, the vice-chancellor and principal, Sir Charles Grant Robertson, gives the figures for the number of students. The total for the past session was 1890, which approaches the maximum reached in the "boom" period after the War. The new entries for the present session also show a marked increase. The postponement for a year (on account of national financial stringency) of the building of the new Hospital Centre and Medical School is a matter of grave concern, in view of the increasing congestion of the present buildings.

CAmbridGe.-A report of the Syndicate on the Scott Polar Research Institute recommends that steps be taken to proceed with the erection of a polar research institute on the Lensfield site. The generous gift of $£ 4000$ by the trustees of the Pilgrim Fund last year has now made up the capital of the building fund to $£ 12,000$, which is considered sufficient to provide for the cost, equipment, and maintenance of the institute which the Syndicate has in view. The financial board, while raising no objection to the recommendations, has expressed the hope that every effort will be made to increase the endowment of the institute.

London.-Dr. G. F. J. Temple, at present reader in mathematics at the Imperial College, Royal College of Science, has been appointed to the chair of mathematics at King's College, as from Aug. 1.

The William Julius Mickle fellowship for 1932 has been awarded to Dr. Philip Eggleton, for his research on the labile compounds of phosphorus in muscle.

There will be an election to Beit fellowships for scientific research in July next. Applications, upon a form supplied upon request, must be received by April 12 by the Rector, Imperial College of Science and Technology, South Kensington, S.W.7.

THE annual examinations for a Faraday scholarship of eighty guineas per annum, tenable for two years in the Faraday House Electrical Engineering College and one year in a manufacturing works, and for a Maxwell scholarship of sixty guineas per annum, tenable for two years in the College and one year in a works, will be held at Faraday House on April 5-7. Further particulars may be obtained from the Registrar, Faraday House Electrical Engineering College, 62-70 Southampton Row, W.C.1.

THE Rockefeller Foundation's disbursements in 1930 amounted, exclusive of administration expenses, to nearly fifteen million dollars, of which universities and other educational institutions received more than six millions, research institutions and organisations more than two millions, whilst public health work absorbed nearly three, and fellowships and grants-inaid more than one million. The field of the Foundation's activities embraces, in addition to its International Health Division in which expenditure since 1913 has amounted to 42 million dollars, work in the medical sciences, natural sciences, social sciences, and the humanities. In the International Health Division particular emphasis has in recent years been laid on field work, including the gathering of knowledge about widespread maladies such as hook-worm, malaria, pellagra, yellow fever, tuberculosis, and the common cold. All results of researches by members of the field staff of the Foundation or by persons working under its auspices are published (to the number of 57 in 1930) 